\title{
THE SIGNIFICANCE OF KARL BARTH'S THEOLOGY FOR THE BELHAR CONFESSION: AN ANALYSIS OF THEOLOGY OF GERMAN ORIGIN IN SOUTH AFRICA DURING THE APARTHEID EPOCH
}

\section{Rothney S Tshaka}

Department of Philosophy, Practical and Systematic Theology. University of South Africa tshakrs@unisa.ac.za

\section{ABSTRACT}

Academic theology in South Africa was influenced extensively by theology of German origin. This article probes the relationship between theologies that originated in Europe. While there are many perspectives that could be cited to credit apartheid theology for having originated in Europe and in Germany in particular, this article confines itself to a theological influence which challenged apartheid as a sin and a heresy. It looks especially at the influence of the Swiss theologian Karl Barth, who at the time of his critical theological contribution was doing his theology in Germany. The article then refers to the influence of Barmen theology in the origin of the Belhar Confession. A few current challenges are also laid out to conclude.

Key words: Karl Barth; Barmen Declaration; Belhar Confession; apartheid; Germany; South Africa

\section{Introduction}

The relationship between Germany and South Africa stretches from the time shortly after the arrival of Europeans to South Africa. While there have always

\section{UNISA}


been transactions between these two countries, it is the theological transactions that concern us more in this article. The establishment of the Lutheran Church in South Africa is a clear indication of significant interactions between Germany and South Africa. There is no doubt that theology of German origin had impacted greatly on theological life in South Africa. This point is made poignantly clear when one peruses the works of the South African theologian, John de Gruchy. Theological works by the likes of Dietrich Bonhoeffer and Karl Barth were found appealing, especially to those who had refused to engage in a theology that was removed from its socio-economic and political context.

It is for this reason that numerous theological research dissertations on Bonhoeffer and Barth were written by many South African students, both black and white. One of the foremost black students who would engage with black liberation theology was Manas Buthelezi, a Lutheran priest. Many more would force their ecclesiastical traditions to speak to the black reality which was confronting theology in South Africa, especially during the era of legal apartheid. It was the socio-political context of the legal apartheid era that forced contextual theologians to look for theologies that could deal with context and not simply ignore it.

For this reason, theologians from the underside of history were more concerned with a unified approach to the evil of apartheid than with ecclesiastical differences. Therefore it remains clear that the relationship of German theology cannot be confined to Lutheran theology in South Africa only, but must in fact be extended to include ecclesiastical traditions such as the Reformed Church and others. It will become evident that various denominations were able to transcend their traditional differences and focus on a common challenge - such as apartheid in the case of South Africa. This was not something strange, because the very Confessing Movement had transcended ecclesiastical differences when it felt that the integrity of the gospel was at stake during the Nazi epoch. In this article we will explore these similarities. For many in South Africa it became clear that the challenges of apartheid were a direct result of theologised politics. This, it will be observed, was not a uniquely South African phenomenon. In fact, similarities were observed in German theological reflection. It is these similarities between specifically the Barmen Declaration and the Belhar Confession that we hope to probe in this article.

\section{The pre-history of the Barmen Theological Declaration}

The situation in Germany after its defeat in World War I was characterised by great confusion. This propelled many into assuming positions which to them could explain the defeat suffered by the Germans during the war. The collapse of the Weimar Republic was precipitated by an extremely unfavourable combination of political circumstances, both in Germany and abroad. ${ }^{1}$ Although it may be argued that these circumstances might have contributed to the final collapse of the Weimar Republic, the historian Klaus Scholder (1989) surmises that the actual reason for this should 
instead be sought in the fundamental role played by a 'right-wing' opposition which undermined all attempts at political consolidation. ${ }^{2}$

The tale of the birth of the Third Reich cannot adequately be comprehended without reference to the Weimar Republic era. It is perhaps worth mentioning here that the end of the monarchy in Germany also signalled the end of the governance of the church by the ruler of the land. Rohls (1998) argues that, in contrast to the separation of church and state in France, or the situation in Bolshevik Russia, the relation between church and state after the revolution of 1918 was defined not in terms of a strict separation, with the withdrawal of all the public incentives the church had previously enjoyed. ${ }^{3}$

Gorringe (1999) reminds us that the first national assembly was convened in Goethe's theatre in Weimar. The idealism of their great poets and thinkers was supposed to fill the life of their new Republic. Its new constitution, which was endorsed in August 1919, guaranteed freedom of speech and assembly, and rested on the principle that the state's power emanated from the people, but nevertheless vested great emergency powers in the president who was free to choose and dismiss the chancellor. ${ }^{4}$ Others (and Rohls in particular) maintain that this constitution also adopted the basic principles of the constitution of 1848 , i.e. churches received the status of public and legal corporations to which specific privileges were granted and which were legally protected. The constitution guaranteed full freedom of belief and conscience, as well as undisturbed religious practice. Belonging to a specific ecclesiastical tradition neither evoked advantage nor disadvantage. In essence, a state church no longer existed. ${ }^{5}$

The separation of church and state was welcomed by liberalism as well as religious socialism, but frowned upon by the conservatives. It was this separation which consequently gave rise to a movement for a 'People's Church' (Volkskirche). Sontheimer (quoted by Scholder 1998) made a distinction between the old nationalism of the Kaiser's Reich ${ }^{6}$ and the new nationalism which grew out of World War I. He believed that this distinction could be perceived as having ushered in a new era which was characterised by a vehement rejection of Wilhelmism. ${ }^{7}$ This new nationalism, which was also seen as the propagandist of the 'conservative' revolution, was regarded by many as being the real nucleus of the anti-democratic movement. One of its chief characteristics was a passionate rejection of liberal democracy.

Scholder (1989) maintains that although this movement was not in essence opposed to the Republic, it nonetheless cannot be denied that it remained tenaciously opposed to the issues upon which the Republic was founded - the liberal democratic system. ${ }^{8}$ Although the opposition remained stubbornly opposed to such assimilation, the older generation of men such as Ernst Troeltsch, Friedrich Meinecke, Hugo Preus, Max Weber, Friedrich Naumann and Thomas Mann were ready to compromise this undesirable decision. On the other hand, the defeat had created advocates who fused patriotic sentiments with Christian truth. 
The separation between church and state also had further implications for church governance. Thus the 'People's Church movement' - in the form of people's church councils - called for a general German Ecclesiastical Assembly to provide a constitution, as well as for a free electoral system based on the sovereignty of the people in all ecclesiastical offices and church councils. The goal was the establishment of the Free Evangelical People's Church in Germany. ${ }^{9}$

The transfer of actual ecclesiastical authority to the territorial churches led to the individual territorial churches drawing up their own constitutions. These in the main were based on the model of parliamentary democracy and were strengthened by the synods. Rohls (1989) asserts that in most of the churches the ruler of the land as the supreme bishop was replaced by a collegial governing board which consisted of members of the synod and consistories - the latter being formally active as actual ecclesiastical administrative authorities. ${ }^{10}$

The consolidation of the territorial churches found expression in some form of 'territorial Episcopal' office. The constitution of the Weimar Republic fundamentally retained the collegial system with the only difference being that now the elements of a constitutional monarchy were replaced by parliamentary democracy. No direct connection was established between the constitution and the confession of a church. The gradual erosion of the Weimar democracy together with its parliamentary system by the radicalism of the left and especially of the right, was decisive for the further development of the relation between church and state in Germany.

However, the 'German Christians' exploited elements of the conservative revolution as well as social nationalism. The emphasis on race is best understood when one comprehends that, on the one hand, the German people wanted to make sense of a war they had lost and of the numerous reasons cited as justification for the war. On the other hand, another 'war' was being waged in the form of self-assertion of the German spirit over Roman/Anglo-Saxon thought. This manifested in what Scholder (1989) calls the Germans' inability to admit that they had lost the war. ${ }^{11}$

The party platform of the National Socialists had already assumed the position of 'positive Christianity' without any confessional ties, extending freedom of confession only to those confessions which did not offend the ethical and moral sensibilities of the German race. ${ }^{12}$ The notion of race was set above and consequently against that of Christianity, especially since a common notion of Christianity conceded that in Christ there was no difference between Jew and Gentile and that both may be baptised. Cochrane (1976) argues that in the beginning only a few clergymen detected a few warning signs and that very few realised that an anti-Semitic racialism was utterly irreconcilable with Christianity. He comes to this conclusion because he is convinced that many were blinded by Hitler's repeated assurance that he stood for 'positive Christianity' against 'godless Bolshevism'. ${ }^{13}$

The guiding principles of the Faith Movement of German Christians (1932) explicitly adopted the racist elements. ${ }^{14}$ These ideals were to be understood not as a replacement for a confession of faith, but instead as a 'confession of life'. The 
principles argued for a 'people's Reich church' that abandoned the parliamentary system of ecclesiastical politics. They were looking for a church based on a belief in Christ in accordance with the German spirit of Luther and with heroic piety - a belief that regarded race, people and nation as God-given orders of life, and thus forbade any mixing of races. ${ }^{15}$ They called for a new church constitution that would replace the democratic right of election with the principle of suitability, and for a spiritual head of the Reich church, drawn up in accordance with the Führer principle.

The confusion which ensued, placed Barth and others (especially Thurneysen, Bultmann and Gogarten) 'between the times'. It must immediately be pointed out that the period in question may be interpreted theologically as well as politically. Theologically it can be said that this was a period between orthodox Protestantism and the new modern liberal direction indicated by the Barmen Declaration. A new theological pattern which broke radically from the theological pattern of the nineteenth century was introduced. It culminated in the Barmen Declaration.

Gorringe (1999) classifies the period 'between the times' as October 1921 to March 1930, suggesting that the birth of the Weimar Republic signalled the start of this period. When Barth became professor at Göttingen, the Republic was nearly two years underway. McCormack (1997) points out that the Germany to which Barth went in October 1921 was a Germany in the throes of an economic catastrophe.

Peace was signed on 28 June 1919, when the German government acceded to the terms of the Versailles Treaty. ${ }^{16}$ However, the terms of the treaty were devastating. Germany was stripped of all her colonies, Alsace-Lorraine was returned to France, and West Prussia, Upper Silesia and the Posen were given to Poland, thereby splitting East Prussia geographically from the rest of Germany. The military was reduced to 100000 men and the Rhineland was occupied by allied troops to ensure its permanent demilitarisation. What is more, to this treaty was added the 'war guilt clause' in terms of which Germany was to acknowledge sole responsibility for causing the war. As a result, it was further made responsible for compensating the Allied powers for all the losses and damages they had suffered. ${ }^{17}$

It is against this backdrop that the German people at the beginning of the twentieth century are to be understood. Their need for solidarity and mobilisation for the sake of reclaiming Germany for the German people reached its pinnacle in the call by some of the Weimar Republic's leaders. This was accompanied by a strident idealism, especially in the youth movement. Gorringe (1999) holds that on the right this centred on the exaltation of the German Volk, whereas on the left there was a striving, often pacifist idealism. Working-class Communists remembered Weimar as a hopeful time, when being socialist was self-evident. Both the hope and the faith in German Volkstum were shared by the church.

During this time in Göttingen, Barth plunged himself into the academic world. Although Gorringe (1999) maintains that Barth's years in Germany during this period were extraordinarily productive, the view is held by many that, for Barth 
personally, the decision to become a professor meant a revision of his approach to politics. Barth would not be able to deal with politics in the same manner as when he was a pastor in Safenwil. It can, however, not be maintained that he was not at all involved with politics since he began (with Gogarten and Thurneysen) to focus on 'dialectical theology' - which was also called a 'theology of crisis' - in 1922.

Barth, a man who once entertained the possibility of becoming a labour organiser, would now spend many sleepless nights preparing for classes and studying for lectures. ${ }^{18}$ Hunsinger (1976) is of the opinion that Barth's decision to withdraw from praxis and concentrate on theology's conceptual task coincided with his new political sobriety and his turn to dialectical theology. He adds that despite this greater political sobriety, Barth did not abandon his socialist commitment even at the height of his dialectical period. His 1919 slogan - 'social democrat, but not religious socialist' remained in force, for in 1926 he could still speak of 'the justice and necessity' of the socialist struggle while castigating theology and the church for not having supported the legitimacy of the socialist cause. ${ }^{19}$

It is by locating Barth's theology against this cultural and intellectual background that Gorringe's (1999) assertion that Barth's theology was thoroughly contextual, is justified ${ }^{20}$ His struggle to find his feet in that confusing context also impelled him to see himself as existing 'between the times', a notion which explained the confusion he and his contemporaries felt and which was crystallised in the founding of the theological journal Zwischen den Zeiten (Between the Times). Barth founded this journal together with Gogarten and Thurneysen in August 1922 as a theological counterpart to other famous Weimar journals. Its sole intention was to oppose the hitherto dominant liberal theology and to promote a theology of the Word. Barth's academic activities kept him busy to a large degree; some, especially Ragaz (quoted in Gollwitzer 1976) thought that this was merely a ploy on his part to disregard the reality of politics. ${ }^{21}$

\section{Germany in a state of theological and political emergency}

The Confessing Church, led by Martin Niemöller (a one-time sympathiser of the Hitler ideology) opposed the Nazification of the Protestant churches. He rejected the Nazi racial theories and denounced the anti-Christian doctrines of Rosenberg and other Nazi leaders. It is conceivable that Barth was at times quiet given the demands of his academic activities, but it is inconceivable that he was ever neutral when it came to political matters. Whether he actively opposed a diabolical regime (as in the case of Nazi Germany) or preferred to adopt a rather inactive approach to the other (as is the case with the East-West conflict), Barth clearly manifested his theopolitical position.

The idea that one can never look at the political issues and pretend that 'all cats seem grey', propelled Barth into party politics. However, he had to remain cautious of party-political snares. To this effect Barth (1977) wrote in his commentary on 
Romans that 'a political career becomes possible only when it is seen to be essentially a game; that is to say, when we are unable to speak of absolute right, when the note of "absoluteness" has vanished from both the thesis and the antithesis, and when room has perhaps been made for that relative moderateness or for that relative radicalism in which human possibilities have been renounced'. ${ }^{22}$

This approach to party politics therefore reveals Barth as a person who engaged in politics without becoming a slave to it. It is for this reason that he wrote in 1915 that "I regard the "political pastor" in any form as a mistake, even if he is a socialist. But as a man and a citizen...I take the side of the Social Democrat'. ${ }^{23}$ This helps us to understand the claims made by some that Barth treated his membership of Religious Socialism in a most anarchical way, as a peripheral matter in which he was every bit as quick to criticise the party as to support it. It was this very same attitude that impelled him to warn that we dare not put our 'hearts' into our politics; that our political careers must be treated as 'a game'; ${ }^{24}$ and that, above all, we dare never use 'God' (i.e. religion, theology, Christianity) as justification or support for what are actually our own political ideologies. ${ }^{25}$

In what follows, attention will be given to the question of why a status confessionis was considered inevitable at a certain point in the history of the German church. The next section will clarify the humility of a Reformed confession, i.e. a Reformed confession is not something that elevates the group that promulgates it above those who are making a mockery out of the gospel; instead it is made with the deepest conviction that the church cannot do anything else but confess.

\section{The theological-political situation in Germany: A stimulus for the Barmen Theological Declaration of 1934}

The Barmen Declaration was given form by this Confessing Church in Germany. The Confessing Church had grown from the 'Pastors' Emergency League' which was founded by Martin Niemöller in 1933. It took its name from the fact that it based its opposition to Hitler and the 'German Christians' on the confession of faith in Jesus Christ as the one Lord and source of belief. ${ }^{26}$

One way of looking at the formation of this movement, and therefore also of the Barmen Declaration, is to see it as a reaction against the 'German Christians'. Some, however, challenge this view. Busch (1976) remarks in an article presented at one of the International Reformed Theological Institute (IRTI) conferences that 'the Barmen Declaration did not object directly to the Nazi government, and the reason for it was simply that just in these months the government ruled cautiously and especially it did not interfere in the church affairs. But in those days the Protestant church revealed its susceptibility to the new mottos of the nation, volk, the race and the Führer, to a shocking degree'. ${ }^{27}$ 
This movement in itself has not escaped criticism. A part of these criticisms was informed by the view that it did not resist Hitler per se. Busch (1976) describes the Confessing Church's resistance to Hitler and the theological underpinning which was given to his rule as pathetic. He writes:

Not only was the Confessing Movement pathetic because it did not oppose Hitler and his ideologies directly, but so did the Barmen Declaration also lag behind when it came to the physical opposition of Hitler. ${ }^{28}$

Harinck (2003) joined this chorus. He also blames the Bekennende Kirche for not taking adequate action against Hitler and his regime. He considers it as selfish because it did not oppose Hitler and his ideologies in essence, but was opposed to the fact that the state was dictating how the church should conduct its business. Harinck (2003) asserts that: 'de Bekennende Kirche was alles behalve anti-national-socialistisch' ${ }^{29}$

Despite its 'insufficient' action in responding to Hitler as well as its 'insufficient' solidarity with the cause of the Jews, the Confessing Church was correct in its judgment that the theological and political situation in the 1930s in Germany warranted a status confessionis. This materialised during the Synod of Barmen in 1934.

This group became the voice of Nazi ideology within the Evangelical Church; it even went to so far as to advocate the removal of the Old Testament from the Bible. In the summer of 1933, citing the state Aryan laws that barred all 'non-Aryans' from the civil service, the German Christians proposed a church 'Aryan paragraph' to prevent 'non-Aryans' from becoming ministers or religious teachers..$^{30}$

Retrospectively, it has to be understood that the Confessing Church in Germany was not precipitated by Hitler's notorious legislations and his National Socialism (NS). Instead, this movement was precipitated by the theological hermeneutics of the 'German Christians' who were comfortably at home with natural theology and thus saw no danger in advocating an Aryan paragraph for the church as well. Even Barth thought that the NS with its teachings of the Germans as superior to other nations could be construed as being innocuous if this were not incorporated into Christian teachings, as was done by the German Christians. ${ }^{31}$.

Hunsinger (1976) reports that Barth himself pointed out in 1942 that most of the members of the Confessing Church 'thought they could agree to, or at least sympathise with, the political and social aims of National Socialism'. ${ }^{32}$ Barth furthermore admitted that up until the year 1934 while he was still in Germany, he thought that he could relegate his political opposition to the background and work along the lines of resisting Nazi intrusion in church affairs. ${ }^{33}$ When Hitler appointed Bishop Muller to the office of protectorate for the German Christians, it became clear to the Evangelical Church that Muller was no longer a mere liaison between Hitler and the church, but had become a representative of a party in the church. The Confessing Church had to seriously take a stand of resisting forces which threatened to dictate its affairs. 
This threat was contained in the state's attempt to determine who made up the church's membership, hence the status confessionis. ${ }^{34}$ The Confessing Church was constituted by diverse Christian theological traditions such as Lutheran, United and Reformed. During the conception of the Barmen Declaration, Barth was confronted with the enormous challenge of having to also accommodate the Lutherans. Barth was impressed by the consensus that was reached between the Reformed and Lutheran groups present.

\section{The historicity of the Belhar Confession of the URCSA}

The word apartheid has become synonymous with South Africa. In 1982 a status confessionis was declared by the then Dutch Reformed Mission Church (DRMC) in the suburb of Belhar, which is located in the Cape Town vicinity. The DRMC realised that apartheid in South Africa was more than a political situation imposed on the South African society. Apartheid was exposed as a comprehensive ideology and view of life involving the organisation and control of humanity and society with the pretence of a pseudo-gospel. The Belhar Confession rejected this as a heresy, as indicated in its three articles..$^{35}$

Similarities between the Barmen Theological Declaration and the Belhar Confession are immediately distinguishable. The Barmen Theological Declaration was opposing the Nazification of the church. Similarly, the Belhar Confession was opposing the theologised politics of the apartheid regime. The Barmen Theological Declaration stressed the Word of God, which is the only Word that must be heard and obeyed. Similarly, the Belhar Confession emphasised the primacy of the Word of God. The Barmen Theological Declaration was economical with the usage of political language; likewise the Belhar Confession opted for stronger theological language in contrast to political language.

Apartheid refers to the idea of separate development. There are numerous authors of this concept, but it is important to note that this concept met its pivotal significance under H.F. Verwoerd. Although it claimed that its chief objective was to assist all groups to develop to the best of their own potential, it was not as innocuous as it sounded, given the fact that the white group always retained its superiority over other groups. It was this very group which in essence determined the lives and degree of development of the subordinate groups. In a sense, apartheid actually created ubermenschen and untermenschen - with the white race perceived to be the former while the black people perceived to be the latter.

The Belhar Confession of the URCSA was not the only theological statement that challenged the biblical justification of apartheid and which had as its impetus the Barmen Theological Declaration. Indeed, quite a few South African theological statements which credit the Barmen Theological Declaration can be cited; they include among others: The Message of the People of South Africa (1968); the Declaration 
of Faith for the Church in South Africa of the Presbyterian Church (1973); the Koinonia-Declaration (1970); the Theological Declaration of the Broerderkring of the Dutch Reformed Church (1979); the Five Articles of the Theological Basis of the Alliance of Black Reformed Christians in South Africa (ABRECSA) (1981); and the Open letter of 123 ministers of the Dutch Reformed Church (1982). In a sense therefore, the Belhar Confession departs from the Barmen Declaration because of the difference in understanding and interpreting the notion 'confession'.

\section{Difference between Lutheran and Reformed understandings of confessions}

It is imperative to note that Lutheran confessions were generally written in brief periods (Leith 1973) and were primarily aimed as a response to the issues facing a specific geographic area. ${ }^{36}$ Barth (2002) displays at least five points which characterise a Lutheran confession. ${ }^{37}$ These characteristics are briefly summarised as follows:

a. Lutheran confessions intend to be ecumenical in character. This suggests that Lutheran confessions endeavour to be seen as having the same dignity and validity as the confessions of the one ancient imperial church of Europe. A confession of this nature thus aspires at all times not to be a private declaration but purposefully wants to be public.

b. The Lutheran Church insists on the essence of unity as well as a united interpretation of its confessions. This is especially prevalent in the Augsburg Confession, which had secured its position as a confession that embodied the ecumenicity of the Lutheran Church. More importantly, this confession bears testimony to the intention of its authors that it never wanted to depart from ancient confessions that preceded it.

c. A public confession of the Lutheran Church has the character of a symbol. Because such a confession is given the status of a symbol, such a confession is then compared with the classical creeds such as the Nicene Creed.

d. A Lutheran confession tends to command authority. Because it is seen as an authoritative confession, it is claimed that such a confession cannot be changed or be replaced.

e. The authority which this confession claims obligates those who teach it to concede to the inerrancy of this confession. Barth (2002) maintains that seen in such a way, it is revealed that 'upon this confession rests, albeit in a subordinate way, the sacredness and necessity of the revealed Word of God itself'.

In contrast to the Lutheran understanding and interpretation of a confession, a confession is not seen according to the reformed faith as being on the same level as the classical creeds which are also called symbols. ${ }^{38}$ Confessions are seen in the 
reformed church as not being on the same plain as symbols because they have to be re-examined from time to time in order to be able to speak to the cultural existence at particular moments in history. Barth (quoted in Tshaka 2005) succinctly summarises the essence of seeing confessions as contemporary statements of faith that are in constant need of re-examination, accordingly: '[confessions are] a trumpet blast which needs to be blown in our sick time', ${ }^{39}$

This interpretation and understanding of a reformed confession is best articulated when the idea of re-examination is taken in line with Barth's 1925 response to the World Council of the Alliance of Reformed Churches which was held in Cardiff (see footnote 1). Unlike an understanding prevalent in Lutheranism where confessions are interpreted as being on the same significant level as creeds, reformed confessions - because they constantly have to be re-examined - are compared with a bell and the mighty sound that it makes. The mighty sound dies away gently. It is for this reason that Barth (2002) contends that the significance of the confession in the Reformed Church consists in its essential nonsignificance, its obvious relativity, humanity, multiplicity, mutability and transitoriness. ${ }^{40}$

A reformed confession is seen as such because it wants and aspires to point beyond itself. Because it aspires to point beyond itself, it must be said that a reformed confession points beyond its history. It does not nullify and vilify this history, but because it knows that its purpose is simply to confess the revelation of Christ in Scripture in a particular current context where this confession is made, it is unable to use history as a means of underpinning how Christ continues to reveal himself to his church. The principle of Scripture which retains a fundamental role in dealing with confessions, forces a confession against the wall and renders it so fragmented, so desecrated, so human and temporal, so minimally binding. ${ }^{41}$

\section{Conclusion}

While the Belhar Confession has been credited as being one of the bold attempts by the reformed faith in South Africa, it remains inevitable that there are still many challenges with which theology is being faced in present day South Africa. This confession went on to become one of the statements of faith adopted by churches across the globe. It remains clearly a confession of her time and the historicity that propelled this confession into existence must not be discounted. Like the Barmen Declaration before the Belhar Confession, many today have wondered if the neutral position adopted against a diabolic regime is not to be regretted. I refer especially here to the accompanying letter which served the purpose of allaying the fears of the then apartheid regime. Yet, this concern must take into account the volatile situation out of which Belhar originated. That said, we cannot justify a spirit of timidity and in line with the traditional understanding of any reformed confession, we are to remember that a confession always emerges when the church is of the view that the very matters that are perceived to be neutral matters, threaten the very 
heart of the Christian gospel. For Belhar, apartheid was clearly that perceived neutral matter which had to be confronted head on. With the Belhar Confession, we have come to realise first hand that theology cannot be isolated from the socio-economic, cultural and political contexts in which it finds itself. We then are forced to look at the many works of Barth after the adoption of the Barmen Declaration in which he played such a significant role. Many have criticised the Barmen Declaration for not saying enough in dealing with the Jewish question. It then follows naturally that many must start to interrogate the Belhar Confession more than 25 years after it was drafted. This is so because the issue of race is yet to be dealt with meaningfully within reformed churches in South Africa. Racism and systemic racism in particular, is the overarching challenge which envelopes issues of poverty and other challenges which Africa - and South Africa in particular - have come to be associated with.

This overarching challenge can therefore also be cited for other challenges that black people in particular are faced with across the globe. There are many other challenges that are competing for the attention of living theology; poverty, HIV/ AIDS, the land question, the huge divide between the rich and poor, and so forth. It is also clear that many communities still find themselves to exist on the edges of society. Among others, we must include our gay and lesbian brothers and sisters, differently-abled persons, and so forth. This can only enjoy the necessary attention when theological reflection appreciates that truth is not dogma but that truth is always derived during interaction. The Belhar Confession, like the Barmen Theological Declaration, must therefore be allowed to be critiqued and questioned so that by so doing, new perspectives are derived to confront the numerous other challenges faced by the church and civil society today.

\section{ENDNOTES}

1. Cf. Rohls, J. 1998. Reformed confessions: Theology from Zurich to Barmen. Louisville: Westminster Press, p. 274.

2. Cf. Gorringe, T. 1999. Karl Barth against hegemony. New York: Oxford University Press, p. 74.

3. Cf. Rohls, J. 1998, 274.

4. In 1888 Kaiser Wilhelm II (1853-1941) became the ninth King of Prussia and the third Emperor of Germany. He dismissed the German Chancellor Otto Bismarck two years after assuming his position as Kaiser. Wilhelm was known to be a stern opponent of parliamentary democracy; the result was that he instead acted as an autocratic monarch. Wilhelm was also a devout adversary of socialism. He was nonetheless a zealous supporter of militarism and imperialism. Although Wilhelm was a grandson of Queen Victoria, he pursued an anti-British foreign policy. Because of this, his relationship with Britain was perceived to be controversial, for although he admitted that he did not want to get embroiled in a war with Britain, Wilhelm nonetheless supported South Africa during 
the Anglo-Boer War (1899-1902), assisting Boers. This war was fought between the British and the descendants of the Dutch who had settled in South Africa. For a thorough discussion on the person of Wilhelm, his abdication and exile to the Netherlands in 1918, cf. Clark, C. 2000. Kaiser Wilhelm II: Profiles in power. Essex: Pearson Educational.

5. Sontheimer cited in Scholder, K. 1989, 36.

6. Cf. Scholder, K. 1989, 38.

7. Cf. Rohls, J. 1998, 274.

8. Cf. Rohls, J. 1998, 274.

9. Cf. Scholder, K. 1989, 40.

10. Cochrane, A. 1976. The church's confession under Hitler. Pittsburgh: Pickwick Press, p. 35; Hitler's party - the National Socialist German Workers' Party (Nationalsozialistische Deutsche Arbeiterpartei - NSDAP) spelled out its position towards Christianity in point 24 of its constitution. This point reads: 'We demand freedom of all religious confessions in the state, insofar as they do not endanger its existence or conflict with the customs and moral sentiments of the German race. The party as such represents the standpoint of a positive Christianity, without tying itself to a particular confession. It fights the spirit of Jewish materialism within us and without us and is convinced that a lasting recovery of our Volk can only take place within, on the basis of the principle: public need comes before private greed' (cf. Steigmann-Gall, R. 2003. The Holy Reich: Nazi conception of Christianity, 1919-1945. Cambridge University Press, p. 14).

11. Cochrane, A. 1976, 36.

12. The details of these principles are contained in: Cochrane, A. 1976, 222.

13. Cf. Rohls, J. 1998, 275.

14. Cf. McCormack, B. 1997. Karl Barth's critically realistic dialectical theology: Its Genesis and development 1909-1936. Oxford: Clarendon Press, p. 291.

15. Cf. McCormack, B. 1997, 291.

16. Cf. Gollwitzer, H. 1976. 'The kingdom of God and Socialism in the theology of Karl Barth'. In Karl Barth and radical politics, G. Hunsinger ed. Philadelphia: Westminster, p. 106.

17. Hunsinger, H. 1976. 'Towards a radical Barth'. In G. Hunsinger ed..., p. 217.

18. Gorringe, T. 1999, 78.

19. Cf. Gollwitzer, H. 1976. 'The kingdom of God and Socialism in the theology of Karl Barth.’ In G. Hunsinger ed., p. 79.

20. Barth, K. 1977. The epistle to the Romans. Trans. E. Hoskyns. London: Oxford University Press, p. 489.

21. Barth, K. cited in E. Busch, 1976, 88.

22. Barth, K. 1977, 489.

23. Barth, K. cited in G. Hunsinger,'Towards a radical Barth', 1976, 208.

24. Busch, E. 1976, 235.

25. Cf. Busch, E. 2002. 'The Barmen Declaration: Its theology, background and reception.' In Studies in Reformed theology: Faith and Ethnicity, Vol 1, A.J.G. van der Borght et al. eds. Meinema: Zoetermeer, p. 64. 
26. Cf. Busch, E. 2002. 'The Barmen Declaration: Its theology, background and reception.' In Studies in Reformed theology... p. 64.

27. 'The Confessional Church was all but anti-national socialist.' Cf. Harinck, G. 2003. 'Tussen Barmen en Amsterdam'. Rede uitgesproken bij de aanvaarding van het ambt van bijzonder hoogleraar. 6. Juni, p. 9.

28. Cf. Cochrane, A. 1976, 74.

29. Hunsinger, G. 2000, 78.

30. Hunsinger, G. 2000, 78.

31. Hunsinger, G. 2000, 78-9.

32. Cf. Smit, D.J. 1984. 'What does status confessionis mean?' In A moment of truth: The confession of the Dutch Reformed Mission Church 1982, D.J. Smit and G. Cloete eds. Grand Rapids, Michigan: Eerdmans; Busch, E. 1976; Cochrane, A. 1976.

33. Cf. Durand, J. 1984. 'A confession : Was it really necessary?' In A moment of truth: The confession of the Dutch Reformed Mission Church 1982, D.J. Smit and G. Cloete eds. Grand Rapids: Eerdmans, p. 36.

34. Cf. Leith, J. 1973. Creeds of the churches: A reader in Christian doctrine from the Bible to the present. Oxford: Basil Blackwell, p. 61.

35. Cf. Barth, K. 2002. The theology of the Reformed Confessions, p. 1-7.

36. Reformed theology insists on the distinction between creeds and confessions.

37. Barth, K. cited in R.S. Tshaka 2005. Confessional theology? A critical analysis of the theology of Karl Barth and its significance for the Belhar Confession. Unpublished DTh dissertation. University of Stellenbosch, p. 45.

38. Barth, K. 2002. The theology of the Reformed Confessions, p. 38.

39. Barth, K. 2002. The theology of the Reformed Confessions, p. 40.

\section{LIST OF REFERENCES}

Barth, K. 1977. The epistle to the Romans. Trans. E. Hoskyns. London: Oxford University Press.

Barth, K. 2002. The theology of the Reformed Confessions. Trans. D. Guder and J. Guder. Westminster: John Knox Press.

Busch, E. 2002. 'The Barmen Declaration: Its theology, background and reception.' In Studies in Reformed theology: Faith and Ethnicity, Vol. 1, A.J.G. van der Borght et al. eds. Meinema: Zoetermeer, p. 64.

Clark, C. 2000. Kaiser Wilhelm II: Profiles in power. Essex: Pearson Educational.

Cochrane, A. 1976. The church's confession under Hitler. Pittsburgh: Pickwick Press.

Gollwitzer, H. 1976. 'The kingdom of God and Socialism in the theology of Karl Barth.' In Karl Barth and radical politics, G. Hunsinger ed., p.. 79.

Gorringe, T. 1999. Karl Barth against hegemony. New York: Oxford University Press.

Harinck, G. 2003. 'Tussen Barmen en Amsterdam'. Rede uitgesproken bij de aanvaarding van het ambt van bijzonder hoogleraar. 6 . Juni.

Hunsinger, G. ed. 1976. Karl Barth and radical politics. Philadelphia: Westminster. 
Leith, J. 1973. Creeds of the churches: A reader in Christian doctrine from the Bible to the present. Oxford: Basil Blackwell.

McCormack, B. 1997. Karl Barth's critically realistic dialectical theology: Its Genesis and development 1909-1936. Oxford: Clarendon Press.

Rohls, J. 1998. Reformed confessions: Theology from Zurich to Barmen. Louisville: Westminster Press.

Shirer, K. 1961. The rise and fall of the Third Reich. London: Secker and Warburg

Scholder, K. 1989. A requiem for Hitler: And other new perspectives on the German church struggle. Philadelphia: Trinity Press International.

Smit, D.J. and G. Cloete eds. 1984. A moment of truth: The confession of the Dutch Reformed Mission Church 1982. Grand Rapids, Michigan: Eerdmans Publishing Company.

Steigmann-Gall, R. 2003. The Holy Reich: Nazi conception of Christianity, 1919-1945. Cambridge University Press.

Tshaka, R.S. 2005. Confessional theology? A critical analysis of the theology of Karl Barth and its significance for the Belhar Confession. Unpublished DTh dissertation. University of Stellenbosch.

Van der Borght, A.J.G., D. van Keulen and M. Brinkman eds. 2002. Studies in reformed theology: Faith and ethnicity, Vol 1. Meinema: Zoetermeer. 